ISSN 1997-5902

\title{
Ethnicity and gender variability in the diversity, recognition and exploitation of Wild Useful Fungi in Pobè region (Benin, West Africa)
}

\section{Codjia JEI ${ }^{1 *}$ and Yorou NS ${ }^{2}$}

1. Ecole Nationale Supérieure des Sciences et Techniques Agronomiques de Kétou (ENSTA/ Ketou), BP 95 Kétou, Benin.

2. Faculté d'Agronomie, Université de Parakou, BP 123, Parakou, Benin.* Corresponding author: evans_codjia@netcourrier.com

Original submitted in on $12^{\text {th }}$ February 2014. Published online at www.m.elewa.org on $30^{\text {th June }} 2014$. http://dx.doi.org/10.4314/jab.v78i1.14

\section{ABSTRACT}

Objective: The ultimate goal of this study is to contribute to the enhancement of the livelihood of rural communities through a sustainable exploitation of Non Timber Forest Products, especially the Wild Useful Fungi (WUF).

Methodology and results: The study was undertaken in Pobè area located in Southeastern part of Benin (West Africa). Ethnomycological surveys were accomplished within three ethnic groups (Nago, Holli, Fon) from five (05) villages notably Ahoyéyé, Akouho, Igana, Issaba and Towe. We applied proportional sampling techniques to select 84 respondents. The semi-structured and unstructured interviews were conducted within the sampled population, using standardized ethnomycological questionnaires. Classical index such as the Reported Value Use of Gomez Beloz (RVU), Ethnobotanical Use Value (EUV) of a species for a use category, Total Ethnobotanical Use Value (TUV), Diversity Index (DI) and Pielou evenness (EI), as well as the Sorensen index $(\mathrm{K})$ were used to assess the diversity, the level of knowledge, use of wild mushrooms and variability among all three ethnic groups. A total of 19 species including 12 edible ones were recorded, with Collybia sp. and Volaviella volvacea as the commonly exploited mushrooms in the study area (TUV between 2,14 and 2,40). All recorded species are used in the study area either as food, drugs or source of cash incomes. The study revealed a great variability of knowledge, expertise and of the level of exploitation among ethnic groups $(\mathrm{K}<$ $50 \%$ for all three ethnic groups). However, there exists a certain consistency of local know-how among respondents of the same ethnic group $(\mathrm{DI}=0,027<\mathrm{DI} \max =37 / 2$ ). At the opposite, the study suggests that mycological know-how was held by a small group of men and a large group of women $(E I<0,5: 0,0007<0,5$; $0,004<0,5)$ suggesting a differential use of fungal resources by rural communities.

Conclusion and application of results: This study provides key basic data for a sustainable exploitation of Wild Useful Fungi in Pobè region.

Keywords: Diversity, Know-how, uses / use value, value chain, ethnic groups, Wild fungi, Pobè, Benin.

\section{RÉSUMÉ}

Objectif : Cette étude dont l'objectif global est de promouvoir la diversité et les usages des champignons sauvages s'est déroulée dans la commune de Pobè située dans le Département du Plateau. 

in Pobe region, Benin

Méthodologie et résultats : Cinq (05) villages à raison d'un village par arrondissement de la commune de Pobè ont été choisis pour conduire les enquêtes ethnomycologiques. Il s'agit des villages Ahoyéyé, Akouho, Igana, Issaba et Towé. Un échantillon proportionnel á la taille de chacun des 3 groupes ethniques (Nagot, Holli, Fon) a été appliqué et a permis le choix de 84 personnes sur lesquelles les enquêtes ont été conduites. Les entretiens semi-structurés et non structurés ont été conduits au sein de la population échantillonnée pendant la période d'étude (27 août - 29 octobre). De mêmes, les valeurs d'usages ethnobotaniques, l'indice de diversité et d'équitabilité, de même que l'indice $\mathrm{K}$ de Sorensen ont été utilisés pour apprécier la diversité, le niveau de connaissance et d'exploitation des champignons sauvages de même que leur variabilité entre les différents groupes ethniques du milieu. Les différents entretiens ont permis de recenser un total de 19 espèces de champignons dont 12 comestibles et 7 non comestibles. Les différentes espèces inventoriées sont utilisées à des fins alimentaires, commerciales, médicinales et magiques. Du fait de leurs valeurs d'usage plus élevées (comprises entre 2,14 et 2,40) ; les taxa fongiques Collybia et Volvariella volvacea sont les plus exploitées dans le milieu d'étude. L'étude a révélé une certaine homogénéité de savoir et connaissance ethnomycologique entre les membres d'un même groupe ethnique (valeur d'indice des enquêtés ID =0,027< ID max = 37/2). Par contre, il existe une grande variabilité de savoir, savoir-faire et du niveau d'exploitation d'un groupe ethnique à un autre ( $K<50 \%$ pour tous les trois groupes ethniques). Par ailleurs, les différents indices d'équitabilité obtenus ( $\mathrm{IE}<0,5: 0,0007<0,5 ; 0,004<0,5$.) suggèrent que la plupart des connaissances sont détenues par un petit groupe au sein des hommes et par un grand nombre de femmes. Conclusion et application des résultats : Cette étude fournit des données nécessaires pour une exploitation durable des champignons sauvages utiles dans la région de Pobè.

Mots clés : Diversité, Savoir-faire, usages/Valeur d'usage, variabilité, groupes ethniques, champignons sauvages, Pobè, Bénin.

\section{INTRODUCTION}

Non Timber Forest Products (NTFPs) including inter alia edible wild fruits, nuts, vegetables, beverage, bushmeat, edible and medicinal mushrooms are used by tropical African rural populations for their survival and trade (Malaisse, 2010). Forest Food Resources become a major international concern because not only they display a high diversity, of the important role they play in the livelihood of rural communities but mostly because their exploitation raises up important questions relevant to ecosystem conservation. In Benin, though NTFPs are valuable to the rural communities, they gain very little interest from native scientists and decision makers (van der Zon and Grubben, 1976). Until recently ethnobotanical was been assembled on NTFPs by Assogbadjo et al. $(2008,2010)$; Fandohan et al. (2010) and Ekue et al. (2010). Socio-economic importance of NTFPs for local people in Benin was

\section{MATERIAL AND METHOD}

Study environnement: The study was undertaken in Pobè region located in South-Eastern part of Benin (Fig 1). Pobè extends on an area of $400 \mathrm{~km}^{2}$, making up $11 \%$ addressed by Vodouhè et al. (2009). Some NTFPs have a large contribution in African local people's life, where mushrooms constitute a good example. Not only local people of Africa have a large interest in mushroom (Heim, 1977 ; Härkönen et al., 1995 ; Yorou et al., 2014), but local know-how is deep and full of tuition including patterns of edibility, therapeutic medicine, witchcraft (Rammeloo and Walleyn 1993, Walleyn and Rammeloo, 1994 ; Yorou and De Kesel, 2002 ; Guissou et al., 2008). The overall objective of this study is to assess the diversity and promote the use of wild mushrooms in the town of Pobè (South Benin). Specifically, this study aims at: Making an inventory of wild useful mushrooms (edible, medicinal) in Pobè area, and assessing the various uses of wild mushrooms by the local people of Pobè.

of the Plateau Province and $0.46 \%$ of Benin flash (Gassi, 2006). The study area is characterized by a bi-modal climate regime with two raining seasons (from April to 

in Pobe region, Benin

July and September to November) which contrast with two dry seasons (from October to March, and JulyAugust). Pobè is the most humid zone of Benin totalizing about $1300 \mathrm{~mm}$ rainfall annually and 119 raining days, which largely surpasses the national average (CRAPP,2012). The mean temperature is about $28^{\circ} \mathrm{C}$, with March-April being the hottest period. There are two types of soil in the area, including inter alia : ferralitic, vertisol on sedimentary clay of Lama depression and hydromorphic soil (Dansou, 2011). Vegetation is consituted today by dense forest islands, Guinean savannahs and plantation of oil palm tree (Elaeis guineensis Jacq.). The dense forests are composed of numerous species, but the most common are among others Terminalia superba (Engl.) Diels, Triplochiton scleroxylon K. Schum., Dialium guineense Wild., Ceiba pentandra (L.) Gaertn., Afzelia africana (Sm.) Pers., Piptadeniastrum africana (Hook.f.) Brenan, Cleistopholis patens (Benth.) Engl. and Diels, Albizia zygia (DC.) J.F.Macbr., Irvingia gabonensis (Aubry-Lecomte ex O'Rorke) Baill. and mosaics of crops such as : peanut, cotton, maize (Dansou, 2011).

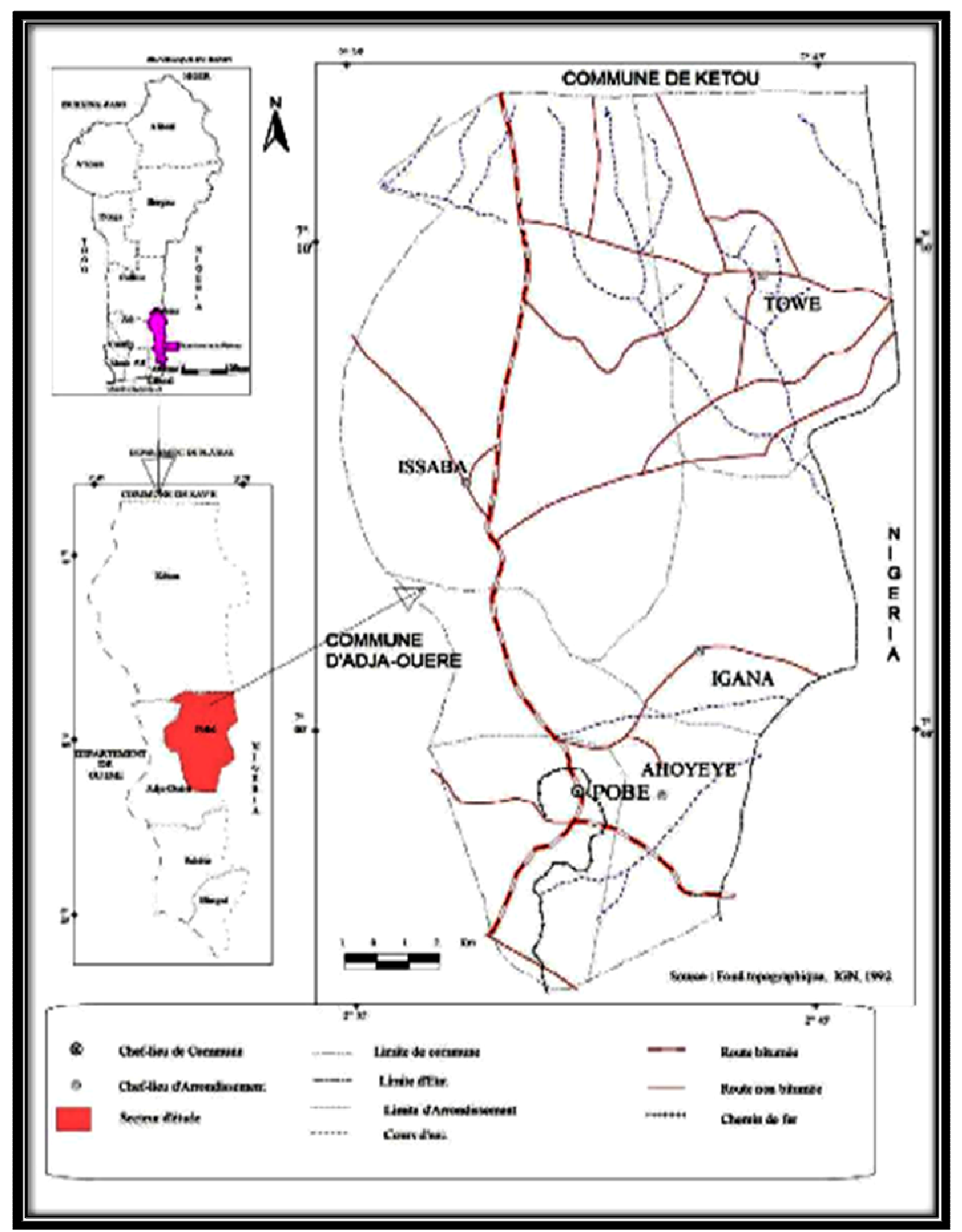

Figure 1: Map of Pobè Province showing the study area in red. Source : Dansou, 2011.

Sampling techniques: Similarly to any region in Benin, the study area hosts a multi-ethnic population among them the tribes of Holli, Nagot, Fon, Aizo, Bariba, Dendi, Ibo, Yoruba (Gassi, 2006) distributed within 32 villages. A 

in Pobe region, Benin

preliminary prospection was carried out in order to sample representative villages from the 32 villages and define adequate sampling size taking into account the size of each ethnic group. A total of 100 people was randomly sampled within the population in 5 District (Ahoyéyé, Akouho, Igana, Issaba and Towé) regardless the ethnic group. All 100 sampled persons were grouped into three categories, notably the young ( 0 - 18 years old), Adults (18 to 35 years old) and Old (over 35 years old). To each of the 100 randomly sampled person, the question «Do you use wild mushrooms ?» was asked. The results of this preliminary surveys are presented in table 1 below.

Table 1 : Random sampling of 100 persons and preliminary record of mushrooms recognition and uses.

\begin{tabular}{|c|c|c|c|c|c|c|c|}
\hline & \multicolumn{3}{|l|}{ Male } & \multicolumn{3}{|l|}{ Female } & \multirow[b]{2}{*}{ Total } \\
\hline & $\begin{array}{l}\text { Young } \\
\text { (0 to } 18 \\
\text { years) }\end{array}$ & $\begin{array}{l}\text { Adults } \\
(18 \text { to } \\
35 \\
\text { years) }\end{array}$ & $\begin{array}{l}\text { old } \\
\text { (over } \\
35 \\
\text { years) }\end{array}$ & $\begin{array}{l}\text { Young } \\
\text { (0 to } 18 \\
\text { years) }\end{array}$ & $\begin{array}{l}\text { Adults } \\
(18 \text { to } \\
35 \\
\text { years) }\end{array}$ & $\begin{array}{l}\text { old } \\
\text { (over } \\
35 \\
\text { years) }\end{array}$ & \\
\hline Positive & 5 & 18 & 25 & 8 & 22 & 16 & 94 \\
\hline Negative & 3 & 2 & - & 1 & - & - & 6 \\
\hline Total & 8 & 20 & 25 & 9 & 22 & 16 & 100 \\
\hline
\end{tabular}

As $94 \%$ of respondents know and commonly use mushroom, the sampling population size was calculated following sampling strategy of Dagnelie (1988) :

$$
N=\frac{U^{2}{ }_{1-\alpha / 2} \times P(1-P)}{d^{2}}
$$

with : $\mathbf{N}=$ the size of the respondents to be considered for detailed investigations, $\mathbf{P}=$ proportion of people knowing and using mushrooms from the preliminary surveys; $\mathbf{U}_{1}$. $a_{2}$ is the value of the Normal random variable at probability value $1-\alpha / 2$. For a probability value of 0,975 (or $\alpha=0,05), U_{1-\alpha / 2} \approx 1,96 ; d(1-\alpha / 2)$ margin error of any parameter to be computed from the survey and a value of $5 \%$ was considered.

\section{$\mathrm{N}=(1.96)^{2} \times 0.94 \times 0.06 /(0.05)^{2}$ \\ $\mathrm{N}=86,66 \approx 87$}

This sampling size was proportionally distributed within all ethnic groups (Table 2).

Table 2 : Sampling size of the population within all ethnic groups

\begin{tabular}{|c|c|c|c|c|c|c|c|}
\hline Ethnic group & $\begin{array}{c}\text { Percentage } \\
\text { (\%) }\end{array}$ & \multicolumn{2}{|c|}{$\begin{array}{l}\text { Respondents per } \\
\text { ethnic group }\end{array}$} & \multicolumn{2}{|c|}{ Male } & \multicolumn{2}{|c|}{ Female } \\
\hline Nagot and Holli & 84,3 & $\begin{array}{c}37 \text { Nagot } \\
\text { of } 73\end{array}$ & $\begin{array}{c}36 \text { Holli of } \\
73\end{array}$ & $\begin{array}{c}18 \text { Nagot } \\
\text { of } 37\end{array}$ & $\begin{array}{c}18 \mathrm{Holli} \\
\text { of } 36\end{array}$ & $\begin{array}{c}19 \text { Nagot } \\
\text { of } 37\end{array}$ & $\begin{array}{c}18 \text { Holli } \\
\text { of } 36\end{array}$ \\
\hline Fons & 12,5 & \multicolumn{2}{|c|}{11} & \multicolumn{2}{|c|}{5} & \multicolumn{2}{|c|}{6} \\
\hline Others & 2,8 & \multicolumn{2}{|c|}{3} & \multicolumn{2}{|c|}{1} & \multicolumn{2}{|c|}{2} \\
\hline Total & 100 & \multicolumn{2}{|c|}{87} & & & & \\
\hline
\end{tabular}

Representative ethnic groups are composed of Holli, Nagot and Fons. All three ethnic groups were considered for further interviews.

Specimens sampling: Forests visits were undertaken in dense forests, fallows and farmlands together with field guides from each ethnic group. Edible fungi were collected directly in the field, and dried after preliminary morphological features were recorded. The protocol of De Kesel et al. (2002) was followed for specimens sampling and conservation. For some specimens, professional pictures were taken directly in the field. The sampled specimens were used to make semi-structured and structured interviews. Whenever needed, a photo guide of edible mushrooms compiled from previous works (De Kesel et al., 2002 ; Yorou et al., 2002) was used to complete the diversity we collected in the field. For 
identification of fungi species we used identification books (De Kesel et al., 2002 ; Eyi-Ndong et al., 2011).

Data analyses: To evaluate the indigenous knowledge of ethnic groups about fungi species, the use frequencies of each species for each use category were given by each respondent. With the help of these frequencies, scores were attributed as follow :

- $\quad$ The species is not used at all : 0

- $\quad$ The species is rarely used : 0.5

- $\quad$ The species is frequently used : 1

- $\quad$ The species is very frequently used : 1.5

These scores attributed allow calculating several classical index such as :

$$
R U V_{i}=\sum_{i}^{n} \text { Species }_{i} \text { Reported Value Use of Gomez Beloz (RVU): }
$$

The total number of use for a species « $e$ » per respondent « $i$ ». However, we determine RUV per ethnic group (and no per respondent) for each species.

$>\quad$ Ethnobotanical Use Value (EUV) of a species for a use category: $E U V_{k}=\frac{\sum_{e} E U V_{e k}}{N}$ $>\quad$ Total Ethnobotanical Use Value (TUV): $T U V_{T}=\sum_{k} E U V_{k}$

Diversity Index $D I=\frac{1}{\sum P_{e}^{2}}$

$P e$ is the number of use cited per respondent « $\mathrm{e}$ » for a species divided by the total of use cited for the species. DI measures how many respondents use the species and how this knowledge is distribute among the respondents. $>\quad$ Pielou evenness ( Equitability Index)

It is Diversity index (DI) value divided by the maximal value of Diversity Index $\left(\boldsymbol{D I} I_{\max }\right.$.

$E I=D I / D I_{\max }$.

This index measures the homogeneity degree of knowledge among respondents. El varies between 0 and

\section{RESULTS}

Diversity of Wild Useful Fungi in Pobè region: A total of 12 edible species and 7 non edible species were collected during the study. The table 3 presents the list of edible species used by each ethnic group along with their
1. In the practice, this index assesses the homogeneity degree of knowledge among all three ethnic group.

The $\mathrm{K}$ Sorensen index was used to assess the diversity, the level of knowledge and use of wild mushrooms and variability among all three ethnic groups. This index is calculated via pair-wise comparison of ethnic groups :

$K=100 \times 2 a /(2 a+b+c)$ with $a$ the number of species used by both ethnic groups, $\mathrm{c}$ is the number of species used by ethnic group 1 and $\mathbf{b}$ that one used by ethnic group 2.

local name and etymologic significance. The following table 4 presents the list of non edible species per ethnic group. The photo 1 presents some edible species recorded in the study area. 
Codjia et Yorou. J. Appl. Biosci. 2014. Ethnicity and gender variability in the diversity of Wild Useful Fungi in Pobe region, Benin

Table 3 : Edible species, local name and preference level

\begin{tabular}{|c|c|c|c|c|c|c|c|}
\hline \multirow[b]{2}{*}{$\mathbf{N}^{\circ}$} & \multirow[t]{2}{*}{ Scientific names } & \multicolumn{3}{|c|}{ local name + appreciation } & \multicolumn{3}{|c|}{ Signification } \\
\hline & & Nagot & Holli & Fon & Nagot & Holli & Fon \\
\hline 1 & $\begin{array}{l}\text { Volvariella volvacea } \\
\text { (Bull.) Sing. }\end{array}$ & $\begin{array}{l}\text { Ohunto èkpè } \\
\text { (1.5) }\end{array}$ & $\begin{array}{l}\text { Ohunto èkpè } \\
\text { (1) }\end{array}$ & $\begin{array}{l}\text { Dékpohunto } \\
\text { (1) }\end{array}$ & \multicolumn{3}{|c|}{ mushroom of palm tree } \\
\hline 2 & Collybia sp. & $\begin{array}{l}\text { Okiki } \\
(1.5)\end{array}$ & $\begin{array}{l}\text { Okiki } \\
\text { (1) }\end{array}$ & $\begin{array}{l}\text { Okiki } \\
(1.5)\end{array}$ & \multicolumn{3}{|c|}{ mushroom that comes out } \\
\hline 3 & Marasmius sp. & $\begin{array}{l}\text { Idjôdou } \\
\text { (1) }\end{array}$ & $\begin{array}{l}\text { Idjôdou } \\
\text { (1) }\end{array}$ & $\begin{array}{c}\text { Idjôdou } \\
(0.5)\end{array}$ & \multicolumn{3}{|c|}{-} \\
\hline 4 & $\begin{array}{c}\text { Lentinus squarrosulus } \\
\text { Mont. }\end{array}$ & $\begin{array}{c}\text { Oluawô } \\
(0.5)\end{array}$ & $\begin{array}{c}\text { Oluawô } \\
(0.5)\end{array}$ & $\begin{array}{l}\text { Ahô } \\
(0.5)\end{array}$ & \multicolumn{3}{|c|}{-} \\
\hline 5 & mushroom sp1 & $\begin{array}{c}\text { Oludèrè } \\
(0.5)\end{array}$ & $\begin{array}{c}\text { Oludèrè } \\
(0.5)\end{array}$ & - & \multicolumn{3}{|c|}{ - } \\
\hline 6 & $\begin{array}{c}\text { Termitomyces letestui } \\
\text { (Pat.) Heim }\end{array}$ & $\begin{array}{c}\text { OKo-adja } \\
(0.5)\end{array}$ & - & - & \multicolumn{3}{|c|}{ - } \\
\hline 7 & $\begin{array}{l}\text { Termitomyces schimperi } \\
\text { (Pat.) Heim }\end{array}$ & $\begin{array}{c}\text { Oluérin } \\
(0.5)\end{array}$ & $\begin{array}{l}\text { Oluérin } \\
(0.5)\end{array}$ & $\begin{array}{l}\text { Oluérin or } \\
\text { Lisso } \\
(0.5)\end{array}$ & \multicolumn{3}{|c|}{ elephant mushroom } \\
\hline 8 & $\begin{array}{l}\text { Marasmiellus inoderma } \\
\text { (Berk.) Singer }\end{array}$ & $\begin{array}{l}\text { Eti-ologbo } \\
(0.5)\end{array}$ & - & - & \multicolumn{3}{|c|}{ - } \\
\hline 9 & mushroom sp2 & $\begin{array}{c}\text { Olubédjé } \\
(0.5)\end{array}$ & $\begin{array}{c}\text { Olubédjé } \\
(0.5)\end{array}$ & - & \multicolumn{3}{|c|}{ - } \\
\hline 10 & mushroom sp3 & $\begin{array}{c}\text { Oluébé } \\
(0.5)\end{array}$ & - & - & \multicolumn{3}{|c|}{ - } \\
\hline 11 & $\begin{array}{l}\text { Psathyrella tuberculata } \\
\text { (Pat.) A. H. Sm. }\end{array}$ & $\begin{array}{l}\text { Oluchichi or } \\
\text { ohunto égui } \\
\text { (1) }\end{array}$ & $\begin{array}{l}\text { ohunto égui } \\
\text { (1.5) }\end{array}$ & $\begin{array}{l}\text { Atinhunto } \\
\text { (1) }\end{array}$ & \multicolumn{3}{|c|}{ Mushroom of tree } \\
\hline 12 & mushroom sp4 & $\begin{array}{l}\text { Akantakpa } \\
(0.5)\end{array}$ & $\begin{array}{c}\text { Akantakpa } \\
(0.5)\end{array}$ & $\begin{array}{c}\text { Akantakpa } \\
(0.5)\end{array}$ & \multicolumn{3}{|c|}{ - } \\
\hline
\end{tabular}

Table 4 : List of non edible species

\begin{tabular}{|l|l|l|l|l|}
\hline \multirow{2}{*}{$\mathbf{N}^{\circ}$} & \multirow{2}{*}{ Scientific names } & \multicolumn{3}{|c|}{ Non edible species } \\
\cline { 3 - 5 } & & \multicolumn{3}{|c|}{ Local names } \\
\cline { 3 - 5 } & & Nagot & Holli & Fon \\
\hline $\mathbf{2}$ & mushroom sp5 & - & Ohunto Dassèboun & - \\
\hline $\mathbf{2}$ & $\begin{array}{l}\text { Leucocoprinus cretatus Locquin } \\
\text { ex Lanzoni. }\end{array}$ & Oluôchôchô & Ohunto édjo & - \\
\hline $\mathbf{3}$ & $\begin{array}{l}\text { Gymnopilus cf. pupuratus } \\
\text { (Cooke and Massee) Singer }\end{array}$ & Ohunto édjo & Ohunto édjo & - \\
\hline $\mathbf{4}$ & $\begin{array}{l}\text { Ganoderma lucidum (Curstis) } \\
\text { Kastern }\end{array}$ & Ohunto édjo & Ohunto édjo & - \\
\hline $\mathbf{5}$ & Pleurotus sp. & Ohunto édjo & Ohunto édjo & - \\
\hline $\mathbf{6}$ & Gymnopilus sp. & Ohunto édjo & Ohunto édjo & - \\
\hline $\mathbf{7}$ & Mushroom sp6 & Ohunto édjo & Ohunto édjo & - \\
\hline
\end{tabular}


Codjia et Yorou. J. Appl. Biosci. 2014. Ethnicity and gender variability in the diversity of Wild Useful Fungi in Pobe region, Benin
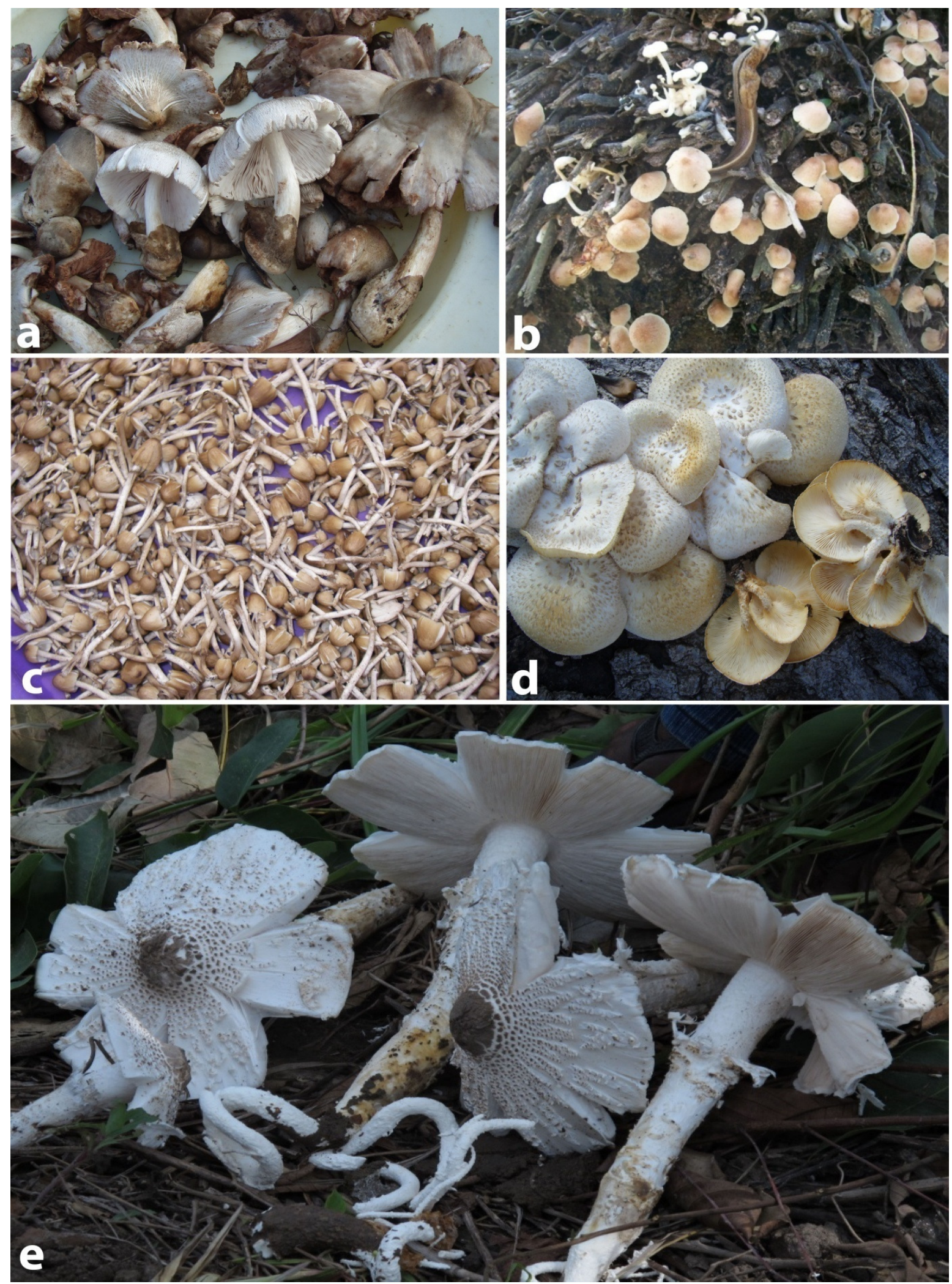

Photo 1: (a - e) : a : Volvariella volvacea. b : Collybia sp. c : Psathyrella tuberculata.

d : Lentinus squarrosulus. e : Termitomyces schimperi. 
Codjia et Yorou. J. Appl. Biosci. 2014. Ethnicity and gender variability in the diversity of Wild Useful Fungi in Pobe region, Benin

Ethnomycologic use value : The uses and use index of each recorded species is presented in table 5 below.

Table 5 : Use value of recorded species calculated per ethnic group.

\begin{tabular}{|c|c|c|c|c|c|c|c|c|c|c|c|c|c|c|c|}
\hline & \multicolumn{5}{|c|}{ Nagot } & \multicolumn{5}{|c|}{ Holli } & \multicolumn{5}{|l|}{ Fon } \\
\hline & \multicolumn{4}{|c|}{ EUV } & \multirow[t]{2}{*}{ TUV } & \multicolumn{4}{|c|}{ EUV } & \multirow[t]{2}{*}{ TUV } & \multicolumn{4}{|c|}{ EUV } & \multirow[t]{2}{*}{ TUV } \\
\hline & $F$ & $T$ & $M$ & $\mathrm{Ma}$ & & $F$ & $T$ & $M$ & $\mathrm{Ma}$ & & $\mathrm{F}$ & $T$ & $M$ & $\begin{array}{l}M \\
a\end{array}$ & \\
\hline $\begin{array}{l}\text { Volvariella } \\
\text { volvacea }\end{array}$ & 1,41 & 0,94 & 0 & 0 & 2,36 & 1,4 & 1 & 0 & 0 & 2,40 & 1,31 & 0,82 & 0 & 0 & 2,14 \\
\hline Collybia sp. & 1,43 & 0,89 & 0 & $\begin{array}{l}0,02 \\
7\end{array}$ & 2,35 & 1,23 & 0,83 & $\begin{array}{l}0,05 \\
5\end{array}$ & $\begin{array}{l}0,02 \\
8\end{array}$ & 2,15 & 1,27 & 0,72 & 0 & 0 & 2 \\
\hline Marasmius sp. & 0,82 & 0,89 & 0 & 0 & 1,72 & 0,81 & 0,86 & 0 & $\begin{array}{l}0,01 \\
4\end{array}$ & 1,69 & 0,45 & 0,14 & 0 & 0 & 0,59 \\
\hline L. squarrosulus & 0,25 & 0,24 & 0 & 0 & 0,5 & $\begin{array}{l}0,05 \\
5\end{array}$ & $\begin{array}{l}0,04 \\
2\end{array}$ & 0 & 0 & $\begin{array}{l}0,09 \\
7\end{array}$ & 0,32 & 0,09 & 0 & 0 & 0,40 \\
\hline mushroom sp1 & 0,23 & 0,20 & 0 & 0 & 0,43 & 0,18 & 0,15 & $\begin{array}{l}0,01 \\
4\end{array}$ & $\begin{array}{l}0,01 \\
4\end{array}$ & 0,36 & 0 & 0 & 0 & 0 & 0 \\
\hline $\begin{array}{l}\text { Termitomyces } \\
\text { shimperi }\end{array}$ & 0,27 & 0,23 & 0 & 0 & 0,51 & 0,18 & 0,16 & 0 & 0 & 0,35 & 0,32 & $\begin{array}{l}0,04 \\
5\end{array}$ & 0 & 0 & 0,36 \\
\hline mushroom sp2 & 0,23 & 0,18 & 0 & 0 & 0,42 & 0,14 & $\begin{array}{l}0,08 \\
3\end{array}$ & 0 & 0 & 0,22 & 0 & 0 & 0 & 0 & 0 \\
\hline mushroom sp4 & $\begin{array}{l}0,09 \\
4\end{array}$ & 0,08 & 0 & 0 & 0,17 & 0,14 & 0,11 & 0 & 0 & 0,25 & 0,13 & 0,09 & 0 & 0 & 0,23 \\
\hline $\begin{array}{l}\text { Gerronema } \\
\text { inoderma }\end{array}$ & 0,13 & 0,10 & 0 & 0 & 0,24 & 0 & 0 & 0 & 0 & 0 & 0 & 0 & 0 & 0 & 0 \\
\hline mushroom sp3 & 0,13 & $\begin{array}{l}0,09 \\
4\end{array}$ & 0 & 0 & 0,23 & 0 & 0 & 0 & 0 & 0 & 0 & 0 & 0 & 0 & 0 \\
\hline $\begin{array}{l}\text { Termitomyces } \\
\text { letestui }\end{array}$ & $\begin{array}{l}0,01 \\
3\end{array}$ & $\begin{array}{l}0,01 \\
3\end{array}$ & 0 & 0 & $\begin{array}{l}0,02 \\
7\end{array}$ & 0 & 0 & 0 & 0 & 0 & 0 & 0 & 0 & 0 & 0 \\
\hline $\begin{array}{l}\text { Psathyrella } \\
\text { tuberculata }\end{array}$ & 0,93 & 0,92 & 0 & 0 & 1,85 & 0,95 & 0,90 & $\begin{array}{l}0,01 \\
4\end{array}$ & $\begin{array}{l}0,02 \\
8\end{array}$ & 1,88 & 0,77 & 0,5 & 0 & 0 & 1,27 \\
\hline
\end{tabular}

Legend:

$\mathbf{F}$ : Food ; T : Trade ; M : medicine ; Ma : Magico-religious, TUV : Total Ethnobotanical use value, EUV : Ethnobotanical Use Value of a species for a use category

Use categories made of wild fungi in Pobè area include: feeding ; trade ; medicine and magico-religious. The use of fungi varies from one ethnic group to another what is checked by the use value calculated (for instance : EUV Holli : 0.028 ; EUV Nagot : 0 ; EUV Fon : 0). Volvariella volvacea and collybia sp (TUV between 2,14 and 2,40 ) are the most used by all three ethnic group.

Variability of indigenous mycological knowledge between ethnic groups: The Diversity and Pielou Evenness values were calculated for each species and per ethnic group in order to measure how the knowledge of the species is distributed within each ethnic group. Table 6 presents results of Diversity Index and Pielou Evenness. 
Codjia et Yorou. J. Appl. Biosci. 2014. Ethnicity and gender variability in the diversity of Wild Useful Fungi in Pobe region, Benin

Table 6 : Diversity Index and Pielou Evenness for each species within each ethnic group

\begin{tabular}{|c|c|c|c|c|}
\hline & & Nagot & Holli & Fon \\
\hline \multirow{3}{*}{ Volvariella volvacea } & $\overline{D I}$ & 0,02 & 0,02 & 0,09 \\
\hline & DI max & 37 & 37 & 11 \\
\hline & $\mathrm{El}$ & 0,0007 & 0,0007 & 0,008 \\
\hline \multirow{3}{*}{ Collybia sp. } & $\mathrm{DI}$ & 0,10 & 0,39 & 0,09 \\
\hline & DI max & 37 & 31 & 11 \\
\hline & El & 0,002 & 0,01 & 0,008 \\
\hline \multirow[t]{3}{*}{ Marasmius sp. } & $\mathrm{DI}$ & 0,02 & 0,06 & 0,36 \\
\hline & DI max & 32 & 31 & 5 \\
\hline & $\mathrm{El}$ & 0,0009 & 0,002 & 0,07 \\
\hline \multirow{3}{*}{$\begin{array}{l}\text { Lentinus } \\
\text { squarrosulus }\end{array}$} & $\overline{D l}$ & 0,04 & 0,30 & 0,28 \\
\hline & DI max & 18 & 4 & 8 \\
\hline & $\mathrm{El}$ & 0,002 & 0,07 & 0,03 \\
\hline \multirow[t]{3}{*}{ mushroom sp1 } & $\mathrm{DI}$ & 0,06 & 0,27 & 0 \\
\hline & DI max & 17 & 13 & 0 \\
\hline & $\mathrm{El}$ & 0,003 & 0,02 & 0 \\
\hline \multirow{3}{*}{$\begin{array}{l}\text { Termitomyces } \\
\text { schimperi }\end{array}$} & $\mathrm{DI}$ & 0,07 & 0,08 & 0,4 \\
\hline & DI max & 20 & 13 & 7 \\
\hline & $\mathrm{El}$ & 0,003 & 0,006 & 0,05 \\
\hline \multirow[t]{3}{*}{ mushroom sp2 } & $\overline{\mathrm{DI}}$ & 0,06 & 0,16 & 0 \\
\hline & DI max & 17 & 10 & 0 \\
\hline & $\mathrm{El}$ & 0,003 & 0,01 & 0 \\
\hline \multirow[t]{3}{*}{ mushroom sp4 } & $\mathrm{DI}$ & 0,16 & 0,11 & 0,44 \\
\hline & DI max & 7 & 10 & 3 \\
\hline & $\mathrm{El}$ & 0,02 & 0,01 & 0,14 \\
\hline \multirow{3}{*}{$\begin{array}{l}\text { Marasmiellus } \\
\text { inoderma }\end{array}$} & $\overline{D I}$ & 0,111 & 0 & 0 \\
\hline & DI max & 7 & 0 & 0 \\
\hline & $\mathrm{El}$ & 0,015 & 0 & 0 \\
\hline \multirow[t]{3}{*}{ mushroom sp3 } & $\overline{D I}$ & 0,12 & 0,12 & 0,12 \\
\hline & DI max & 10 & 10 & 10 \\
\hline & $\mathrm{El}$ & 0,01 & 0,01 & 0,01 \\
\hline \multirow{3}{*}{$\begin{array}{l}\text { Termitomyces } \\
\text { letestui }\end{array}$} & $\mathrm{DI}$ & 0,25 & 0 & 0 \\
\hline & DI max & 1 & 0 & 0 \\
\hline & $\mathrm{El}$ & 0,25 & 0 & 0 \\
\hline \multirow{3}{*}{$\begin{array}{l}\text { Psathyrella } \\
\text { tuberculata }\end{array}$} & $\mathrm{DI}$ & 0,02 & 0,15 & 0,10 \\
\hline & DI max & 37 & 36 & 10 \\
\hline & $\mathrm{El}$ & 0,0007 & 0,004 & 0,01 \\
\hline
\end{tabular}

Data from table 6 showed that there is a relative homogeneity of knowledge within people of same ethnic groups (DI < DI max / 2). The ethnomycological knowledge was more homogenous within Nagot people than in the other ethnic groups since the values of DI for this ethnic group was lower in all cases. The Pielou Evenness measures how the knowledge of a species is distributed between the respondents. El values calculated were relatively low for all investigated species. In all case,
El was lower than 0,5 . This means that the ethnomycological knowledge is held by a small group of men and a large group of women.

Variability of edible species between ethnic groups: The Sorensen similarity test was conducted between ethnic groups taken in pairs. The values calculated for Sorensen similarity test $(\mathrm{K})$ are summarized in Table 7 below. 
Codjia et Yorou. J. Appl. Biosci. 2014. Ethnicity and gender variability in the diversity of Wild Useful Fungi in Pobe region, Benin

Table 7 : Sorensen similarity test between ethnic groups taken in pairs

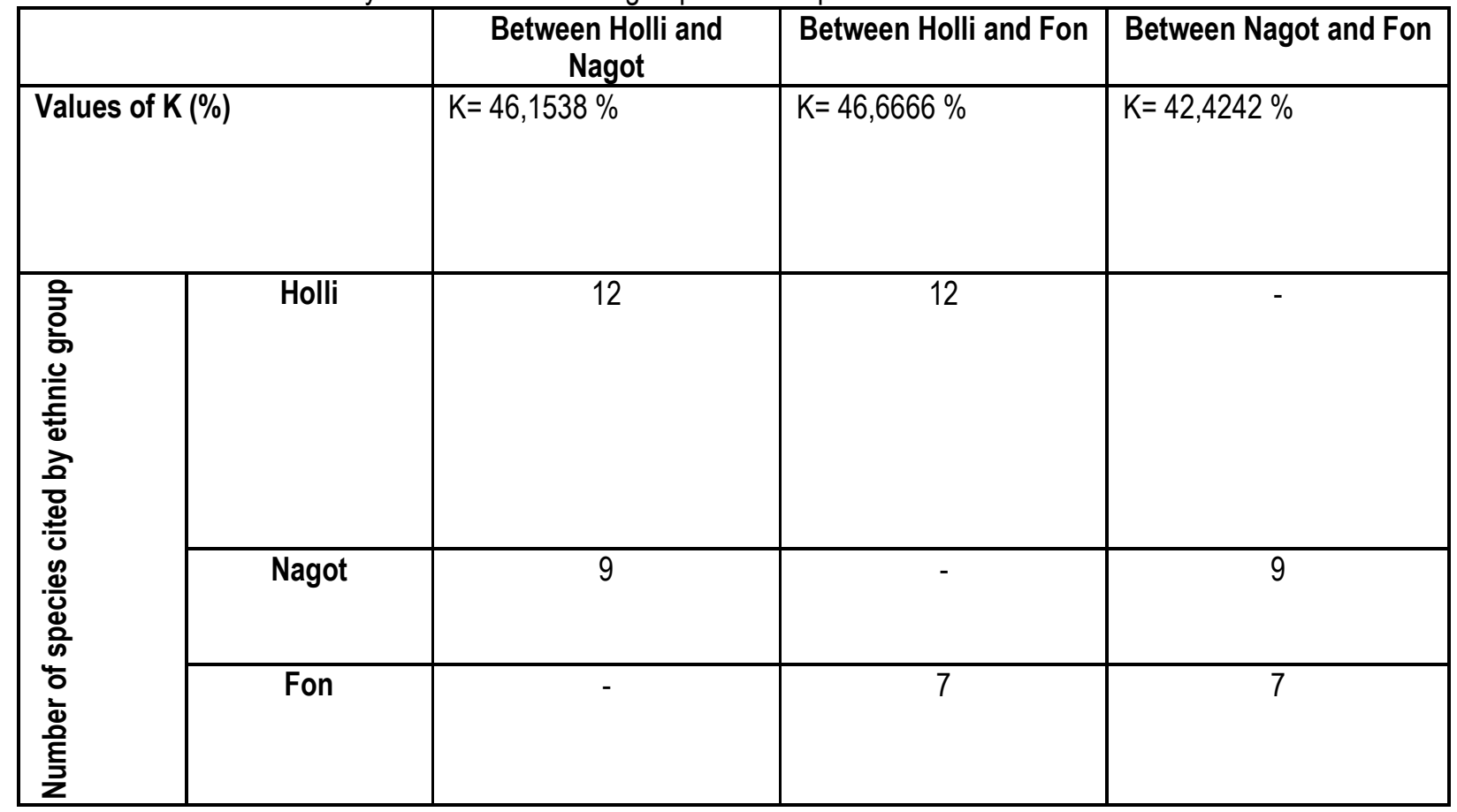

The value of Sorensen similarity Index $(\mathrm{K})$ is lower than 50 in all cases. It means that there is differences in the use of wild mushrooms by the ethnic groups Nagot, Holli and Fon.

\section{DISCUSSION}

Diversity and variability of edible mushroom between ethnic groups : The diversity of edible mushrooms in the study area was high and a total of 12 edible species was recorded. But these species are not fully exploited. In addition to the 12 edible species, 7 non edible species were recorded but still considered by local people as toxic. About fifty macromycete species are consumed by Nagot people of central Benin (Yorou and De Kesel, 2002). For the population Gbaya Bodoé of Centrafrique, Roulon-Doko (1998) had established a list of 60 edible mycotaxa confirming a good mycophagy and knowledge in various areas of this country. Over 60 edible mushroom species have been identified in Tanzania (Buyck et al., 2000; Tibuhwa, 2001; Härkönen et al., 2003). Of all species recorded in the study area, Volvariella volvacea is the most common. The study reveals that all three ethnic groups do not use the same fungal resources and the ethnomycologic knowledge varies from one ethnic groups to another ( $K<50 \%$ in all cases). Similar patterns have been reported in Niger (Hama et al.,2012). Indeed, the populations who live at proximity of forest zones are familiar with the mushrooms (Ducousso et al., 2003) and the knowledge accumulated by the populations is diversified, gathering inter alia: edibility, traditional medicine and other uses (De Kesel et al., 2002). It's the case of Holli in Pobè who hold a large ethnomycologic knowledge because probably they established in the area long time before the other ethnic groups, and thus they are more familiar with the surrounding forests than any other ethnic group.

Culinary significance of wild edible fungi in Pobè region : The species Volvariella volvacea and Collybia $\mathrm{sp}$. are the most exploited species and present same nutritive/food importance as bush meat, fowl and fish (TUV between 2,14 and 2,40). According to respondents, Volvariella volvacea present the same taste as meat. This is in accordance with results from the rural communities in Cameroon where mushrooms are considered as meat for the poor (Van Dijk et al., 2003). The importance of mushrooms, and their uses to supplement/substitute bushmeat is common in many West African countries (Yorou et al., 2014). In Burkina Faso, the mushrooms Phlebopus sudanicus (Har. and Pat.) Heinem. is designated as the meat for the poor by the Bobo ethnic group (Guissou et al., 2005). Collybia sp is also much esteemed because of its sweet taste. On the other side Nagot people from Wari-Maro, prefer larger mushrooms like Termitomyces (Yorou and De kesel, 2002). In general, Termitomyces species range among the most appreciated species in the whole tropical Africa (Yorou et 

in Pobe region, Benin

al., 2014 ; Yorou and De Kesel, 2002 ; Koné et al., 2013). Because of their sporadic and highly spatially variable occurrence that rely upon the presence of intact termites mounds, Termitomyces are unfortunately not always available for consumption. In Central and Eastern Africa, chanterelles are the most consumed wild mushrooms (Yorou et al.,2002 ; Eyi-Ndong et al., 2011 ; Buyck, 1994). The population consume regularly the wild edible mushroom in several countries and they constitute an important contribution to improve nutritive value of daily diets, as showed in a study in Malawi (Abbott, 1999). In Jammu and Kashmir state (India), the majority of people questioned showed deep affection for the taste and preparation of wild mushrooms while only a few respondents showed aversion towards them. It was observed that the larger quantities of mushrooms are being consumed in the area and are regarded by many as an equivalent of meat (Kumar and Sharma, 2011). Majority of consumers in Ghana choose edible mushrooms for their taste, which enhance appetite and in the urban centres, mushrooms are included in soups and stews as delicacies (Apetorgbor et al., 2005).

Medicinal mushroom and use: The species collybia sp., Psathyrella tuberculata, mushroom sp1 are used by Nagot and Holli to cure several diseases. They are used in the treatment of epilepsy, bilharzia, hair lice and scabies. The species are used as well to cure a disease called « Itankpa » that is expressed by a loss of skin of feet palm. Though P. tuberculata is commonly used in Pobè region for therapeutic purpose, the species is unknown by other ethnic groups of Benin (Nagot, Lokpa, Anii, Kotokoli, Bétamaribè and Peulh) who use this species exclusively as food. Many edible mushrooms have also pharmaceutical property. Like in China, the mushrooms are used abundantly in traditional medicine in tropical Africa and in the world. One hundred and eighty two (182) species of medicinal mushroom are recorded worldwide (Wasser and Weis, 1999). In Occidental Niger, the species such as Ganoderma colossus (Fr.) C.F. Baker, Phellinus allardii (Bres.) S. Ahmad and Podaxis pistillaris (L.) Fr. are used for the health treatment of people (Hama et al.,2012). Similar observations are made in Nigeria where mushrooms are used for the treatment of malnutrition in infants, diabetes, obesity or hyperlipidemea, sterility, anaemia, mumps, fever and protein deficiency (Akpaja et al., 2005; Okhuoya and Akpaja, 2005; Idu et al., 2007). In Ghana, it is reported that Volvariella volvacea and Termitomyces robustus (Beeli) R. Heim, when eaten served as blood tonic. Of more, Termitomyces globulus R. Heim and Gooss.-Font. and Termitomyces clypeatus R. Heim, preferred by the
Asantes, Akyems and Akwapims, were also believed to lower blood pressure in hypertensive patients (Apetorgbor et al., 2005).

Use of wild mushroom on magico-religious plan: Nagot and Holli hold an important knowledge about magico-religious use of wild mushroom. It is confirmed by ethnobotanical use value calculated (EUV : $0.028,0.014$ etc.). The species who are used here include Collybia sp., Marasmius sp., "oludèrè " and Psathyrella tuberculata. This species are supposed to bring the luck in the human life. Traders use this species to 'magically " get many customers. Thus, the powder of the cap of these species is used for both cases. The powder is mixed with soap and the trader or human use the mixture during showering. These species are used as love portions. In this case, the powder of any species cited above is mixed with the seed of Aframomum melegueta K. Shum. Similar mythological believes are commonly known by the Nigeria people. Here, the Yorubas used selected mushrooms with psychoactive and hallucinogenic effects for idol worshipping and spiritualism (Oso, 1975; Akpaja et al., 2005; Okhuoya and Akpaja, 2005).

Knowledge and sex influence in the recognition and exploitation of WEF: The study reveals that of all respondents, the women knew mushrooms better than any other groups. Women search for, and pick mushrooms during field works, though the picking is free and none regulated. The women devote more time on mushroom activities above all food and trade. In most societies in Malawi, picking and trading edible fungi are predominantly a female occupation (Morris, 1987, 1994). Generally, there are no standard guidelines to detect edible species from toxic ones. However, ethnic groups use many local criteria to distinguish edible species from non edible species. In general, edibility criteria are linked to the form, color, fatness, hat. All species who present strange colour (yellow) are considered as toxic. These observations have been reported within Nagot people from central Benin, species with strange deeply colored (blue, red) are regarded as bad and non edible (Yorou and De Kesel, 2002). In Subsaharienne Africa, a change of colour of flesh and of their hymenophore, and thus, the majority of Boletus are considered as toxic by the population (Piearce, 1981 ; Thoen et al., 1973). For some population, the change of colour, the disagreeable taste and odour, the tough flesh of mushrooms constitute the proof of toxicity (Eyi-Ndong et al., 2011).

Ethnicity variability in the use of WEF: Use of edible mushroom varies between all ethnic groups interviewed. The value of Sorensen similarity Index (K) calculated 

in Pobe region, Benin

show that not all three ethnic groups Nagot, Holli and Fon use the same fungal resources. The Holli are often in contact with mushrooms, because they are true farmer and the hunter. Therefore, they meet often the species of mushrooms in their field and more at the time of the hunter in the forests where many species are encountered. The Holli are permanent forest residents in the study area. At the opposite, the Fon and Nagot are less farmer than Holli folk. Another fact they may explain differential uses of fungal resources is undoubtedly the differences in instalment history of the ethnic groups. More likely the diversity, and the overall uses made of food resources is positively correlated with the instalment background of each folk. In the study area, the Holli are known as the land owners, meaning that their installement is more ancient than that ones of Fon and Nagot. As such, they are more familiar with the forest, along with forest food resources and the overall forest service they can get is increased. With a more recent instalment history, the Nagot and Fon will need more time to acquaint with the forests. Such differences have been demonstrated by Yorou and De Kesel (2002), Yorou et al. $(2002 a, b, c)$ in central Benin, where the Nagot people (who are land owners in this area) recognise and exploit more than 30 edible species, whereas Lokpa and Yom people of the same village (with relatively recent establishment) use fewer, but almost different species. Hama et al. (2012) reported similar patterns in Niger. Here, the Gourmantché and Peulh as the principal residents of the bush and the forest zones hold more ethnomycologic knowledge than neighbouring ethnic groups Djerma, Touareg and Haoussa. More investigations, addressing establishment history of local folks around forests will help elucidation such differences. Composition and origin of local names of wild mushrooms: In general, local people of Pobè recognize two major groups of fungi : edible and non-edible mushrooms. Edible mushrooms are well known and distinguished. Nevertheless, non edible species are grouped under the same name. The Nagot and Holli call all non- edible mushrooms "ohunto éjo». The mushrooms are called Ohunto or Olu in Nagot as well as Holli. They are called " ohunto » in Fon. On the other hand, the Nagot people from central Benin call the mushrooms « Ossoussou » (Yorou and De Kesel, 2002 ). Sometimes, the generic name of mushrooms is completed by one epithet that often recalls of the habitat, morphology, taste or the ecology. As an example, in Nagot and Holli, palm tree mushroom (Volvariella volvacea) is called " ohunto èkpè » (èkpè means palm tree). Those of tree are generally called « ohunto égui or oluchichi » (égui means tree). Those produced by the termitary are called " ohunto gbodi or oluérin ». In addition, Pleurotus sp. are ranked in the group of non edible mushrooms and are called "Ohunto éjo » (éjo means snake) so all that is related at snake is considered as bad by ethnic groups. It's the case of people in Zambezian Miombo forest who pay no attention to non edible mushroom and hence they have no local name and are systematically considered as poisonous (ukavo or ikoko in Ndendeule and Yao, respectively) (Bloesch and Mbago, 2008). The vernacular names and their etymological significance vary from one ethnic groups to another. It's the case in Niger where the species Ganoderma colossus and Phellinus allardii are locally called « Maarliali » in Gourmantché and means forbid for pregnant women, « Baggy bodjel » in Fulfudé and means hare tomtom (Hama et al., 2012). On the other side, in Jammu and Kashmir state (India) as many as 31 names of 71 wild mushrooms are recorded and transcribed. This vernacular names could be based on gross morphology or based on varied attributes. For instance, Peziza vesiculosa Bull. is recognized as 'Kann Kutch', which means ear like fungus in Kishtwari and Kashmiri. Boletus spp. are called 'Dailoo' (the fungus that breaks easily into pieces) in Bhadarwahi or 'Bhutol' and 'Bhutoo' (edible after roasting on fire) in Bhadarwahi and Gaddaishi dialects respectively. Pleurotus spp. are named as 'Saroori' (meaning growing on different host plants) in Kishtwari; 'Chur Sirer' (growing on Juglansregia) in Kishtwari and Kashmiri languages (Kumar and Sharma, 2011).

\section{ACKNOWLEDGEMENT}

We want to express our sincere thanks to all the population of Pobè for sharing their mycological know-how. Our sincere thanks also go to various guides who help us during this study.

\section{REFERENCES}

Abbott P., 1999. Non-timber forest products harvesting: lessons for seasonally sensitive management in miombo. In M.R. Ngulube, L. Mwabumba \& P.
Chirwa (eds). Community-based management of Miombo woodlands in Malawi: 70-89.

Akpaja E.O., Okhuoya J.A., Eliwer HeferereB.A., 2005. Ethnomycology and indigenous uses of 
mushrooms among the Bini-speaking people of Nigeria: A case study of Aihuobabekun community near Benin City, Nigeria. International Journal of Medicinal Mushroom 7(3): 373-374.

Apetorgbor M.M., Apetorgbor A.K., Nutakor E., 2005. Utilization and cultivation of edible mushrooms for rural livelihood in Southern Ghana. 17th Commonwealth Forestry Conference 2005Colombo, Sri Lanka. 22 .

Assogbadjo A.E., Glèlè Kakaï R., Adjallala F.H., Akomian F.A., Azihou F., Vodouhê G.F., Kyndt T., Codjia J.T.C., 2010. Ethnic differences in use value and use patterns of the threatened multipurpose scrambling shrub (Caesalpinia bonduc L.) in Bénin. Journal of Medicinal Plants Research 5(9): 1549-1557.

Assogbadjo A.E., Glèlè Kakaï R., Chadare F.J., Thomson L., Kyndt T., Sinsin B., Van Damme P., 2008. Folk classification, perception and preferences of baobab products in West Africa: consequences for species conservation and improvement. Economic Botany 62: 74-84.

Bloesch U. and Mbago F., 2008. The potential of wild edible mushrooms in the miombo woodlands of the Selous Niassa Wildlife Corridor for the livelihood improvement of the local population. Mushroom study Selous Niassa Wildlife Corridor. $36 \mathrm{p}$.

Buyck B., 1994. Ubwoba. Les champignons comestibles de l'Ouest du Burundi. Bruxelles, AGCD. 123 $\mathrm{pp}$.

Buyck B., Eyssartier G., Kivaisi A., 2000. Addition to the inventory of the genus Cantharellus (Basidiomycota, Cantharellaceae) in Tanzania. Nova Hedwigia 71: 491-502.

CRAPP, 2012. Rapport final sur les données climatiques. Pobè.

Dansou S.B., 2011. Pluvial erosion and adaptation of people in township of Pobè. Master's degree in the category of art, philosophy and sociology. $75 p$.

De Kesel A., Codjia J.T.C., Yorou S.N., 2002. Guide des champignons comestibles du Bénin. National Botanic Garden of Belgium, Brussels. $135 p+$ $35 \mathrm{pl}$.

Ducousso M., Ba A.M., Thoen D., 2003. Les champignons ectomycorhiziens des forêts naturelles et des plantations d'Afrique de I'Ouest: une source de champignons comestibles. Bois et forêts des tropiques 275(1) : 51-63.

Ekué M., Sinsin B., Eyog-Matig O., Finkeldey R., 2010. Uses, traditional management, perception of variation and preferences in ackee (Blighia sapida K.D. Koenig) fruit traits in Benin: implications for domestication and conservation. Journal of Ethnobiology and Ethnomedicine 6 : 12.

Eyi-Ndong H., Degreef J., De Kesel A., 2011. Champignons comestibles des forêts denses d'Afrique centrale, Taxonomie et identification. ABC Taxa Vol 10. $262 \mathrm{p}$.

Fandohan B., Assogbadjo A.E., Glèlè Kakaï R., Kyndt T., De Caluwé E., Codjia J.T.C., Sinsin B., 2010. Women's traditional Knowledge, use value, and the contribution of tamarind (Tamarindusindica L.) to rural households' cash income in Bénin. Economic Botany 64: 248-259.

Gassi B., 2006. Monographie de la Commune de Pobè. Programme d'appui au démarrage des Communes. 46p.

Gómez-Beloz A., Rucinski J.C., Balick M. J., Tipton C., 2003. Double incision wound healing bioassy using Hamelia patens from El Salvador. Journal of Ethnopharmacology 88 (2003) : 169 - 173.

Guissou K.M.L., Sankara P., Guinko S. 2005.Phlebopus sudanicus ou "la viande des Bobos", un champignon comestible dans le département de Satin au Burkina Faso. Crypto. Myco. 26(3): 195-204.

Guissou K.M.L., Lykke A.M., Sankara P., Guinko S. 2008. Declining wild mushroom recognition and usage in Burkina Faso. Econ. Bot. 62(3): 530539.

Hama O., Ibrahim D., Baragé M., Alhou B., Daniëls P.P., Infante F., 2012. Use of some species of Macromycetes in tradional pharmacopoeia in occidental Niger (West Africa). Journal of Applied Biosciences 57: 4159- 4167.

Härkönen M., Saarimäki T., Mwasumbi L. 1995. Edible mushrooms of Tanzania. Karstenia 35: 1-92.

Härkönen M., Niemelä T., Mwasumbi L., 2003. Tanzanian mushrooms. Edible, harmful and other fungi. Norrlinia 10: 1-200.

Heim R., 1977.Termites and mushrooms. The termitophile mushroom of balck Africa and meridional Asia.Paris, Boubee.207 p.

Idu M., Osemwegie O., Timothy O., Onyibe H.I., 2007. A survey of plants used in traditional healthcare by 
Waja tribe Bauchi State, Nigeria. Plant Archives $7(2): 535-538$.

Kumar S. and Sharma Y.P., 2011. Diversity of wild mushroom from Jammu and Kashmir (India). Proceedings of the 7th International Conference on Mushroom Biology and Mushroom Products (ICMBMP7). Section: Economical and societal features. 568-577 p.

Malaisse F., 2010. How to live and survive in Zambezian open Forest (Miombo Ecoregion). Gembloux, Presses. $422 \mathrm{pp}$.

Morris B., 1987. Common mushrooms of Malawi. Oslo, Fungiflora: $108 \mathrm{p}$.

Morris B., 1994. Bowa: Ethnomycological notes on the macrofungi of Malawi. In J.H. Seyani \& A.C. Chikuni (eds). Proceedings of the XIIIth Plenary meeting of AETFAT, Vol. 1: 635-647.

Okhuoya J.A. and Akpaja E.O., 2005. Mycomedicine and Ethnomycology: The Nigerian Experience. International Journal of Medicinal Mushrooms 7(3): 439-440.

Oso B.A., 1975. Mushrooms and the Yoruba people of Nigeria. Mycologia 67(2):311-319.

Piearce G.D., 1981. An introduction to Zambia's wild edible mushrooms and how to use them. Zambia, Forest Dept. $28 \mathrm{pp}$.

Rammeloo J. and Walleyn R., 1993. The edible fungi of Africa south of the Sahara: a literature survey. Scripta Bot. Belg. 5: 1-62.

Roulon-Doko P., 1998. Chasse, cueillette et cultures chez les Gbaya de Centrafrique. L'Harmattan. Paris. $540 \mathrm{pp}$.

Thoen D., Parent G., lukungu T., 1973. L'usage des champignons dans le Haut-Shaba

(République du Zaïre). Bull. Trim.Centr.EtudesProbl. Soc. Econ. 100-101: 69-85.

Tibuhwa D., 2001. Taxonomy of Termitomyces from Tanzania coastal areas. MSc. thesis, University of Dar es Salaam.

van der Zon A.P.M. and Grubben G.J.H., 1976. Les légumes-feuilles spontanés et cultivés du SudDahomey.Communication 65.Koninklijk Instituut voor de Tropen. Amsterdam.111p.

Van Dijk H., Awana-Onguene N., Kuyper T.W., 2003. Knowledge and utilization of edible mushrooms by local populations of the rainforest of south Cameroon. Ambio. 32:19-23.

Vodouhê F.G., Coulibaly O., Greene C., SinsinB., 2009. Estimating the Local Value of Non Timber Forest Products to Pendjari Biosphere Reserve Dwellers in Benin. Economic Botany 63(4): 397412.

Walleyn R. and Rammeloo J., 1994. The poisonous and useful fungi of Africa south of the Sahara. Scripta Botanica Belgica 10: 1-56.

Wasser S.P. and Weis A.L., 1999. General description of the most important medicinal higher basidiomycetes mushrooms. International journal of Medicinal Mushrooms 1: 351-370.

Yorou S.N. and De Kesel A., 2002. Ethnomycologic knowledge of Nagot in Center of Benin (West Africa). Proceeding of XVI the AETFAT congress, Brussels 2000. Systematic and Geographic of Plants 71: 627-637.

Yorou S.N., De Kesel A, Sinsin B., Codjia J.T.C., 2002a. Diversity and productivity of edible mushroom of Wari-Maro forest. (Benin, West Africa). Proceedings of XVIth AETFAT Congress, Brussels 2000. Systematic and Geographic of Plants 71: 613-625.

Yorou S.N., De Kesel A., Codjia J.T.C., Sinsin B., 2002b. Biodiversity of edible mushroom of Benin. Proceedings of the Symposium-Workshop on Biodiversity in Benin. Abomey-Calavi (Benin) October $30^{\text {th }}$ to November $18^{\text {th }}$ 2002. $231-240$ $\mathrm{pp}$

Yorou S.N., De Kesel A., Sinsin B., 2002c. Preliminary studies of edible larger fungi in Soudanian Woodlands of Benin. $7^{\text {th }}$ congress of the International Mycological Association, Oslo August $2^{\text {nd }}$ to $7^{\text {th }}, 2002$. Abstract book.127 p.

Yorou S.N., Kone A.N., De Kesel A., Guissou M.L., Ekue M.R., 2014. Biodiversity and sustainable use of Wild Edible Fungi in the Soudanian Centre of Endemism : a plea for their valorisation. In Bâ et al (eds). Ectomycorrhizae in the Tropics and Neotropics. CRC Press, Science Publisher. London. 241-269 pp. 